deep insight into how these molecules behave in the dilute, semi-dilute and melt regimes. The authors go lightly with derivations, but the ones they do are easy to follow and well discussed in terms of physical consequences. The explanations of the interplay of entropy and internal energy in the coil-globule transition and phase transitions of polyelectrolyte gels are about the clearest I have read anywhere. The authors strongly believe that understanding the role of the primary, secondary and tertiary structure of biopolymers will become an increasingly important aspect of polymer physics. They put forward probability arguments to speculate about the role of chance in the origin of life and in the evolution of both the chemical and the biological properties of biomacromolecules.

Simple cartoons and colour plates depict the more spatially intriguing aspects of the various molecules and models. An accompanying CD-ROM (produced by $S$. Buldyrev of Boston University) greatly enhances the text, with simulations illustrating, for example, protein folding. What is more, the ambitious reader can alter the program parameters on the CD-ROM to see their influence and even produce customized movies.

Edwin L. Thomas is in the Department of

Materials Science and Engineering, Massachusetts Institute of Technology, Cambridge, Massachusetts 02139, USA.

\section{Oceans of truth}

\section{Cod: A Biography of the Fish that Changed the World}

by Mark Kurlansky

Walker: 1997. Pp. 294. \$21

\section{Johnshepherd}

If you want to know how a flush toilet may help in the cooking of dried or salted cod, what W. H. Auden and Louis MacNeice thought of the product, how it contributed to the causes of the American War of Independence, or why fishing for cod has been banned in Canadian waters for the past five years, you should read this book.

The belief that the oceans and their resources are limitless and invulnerable to harm from human activities persisted for a very long time. In about $400 \mathrm{BC}$, Clytemnestra asked: "There is the sea - who shall exhaust the sea?", in Aeschylus's drama, the Oresteia. In 1883, T. H. Huxley stated: "I believe, then, that the cod fishery... and probably all the great sea fisheries, are inexhaustible: that is to say that nothing we do seriously affects the number of fish. And any attempt to regulate these fisheries seems... to be useless." In the twentieth century, we have successfully disproved these hypotheses. The great whales were reduced almost to extinc-

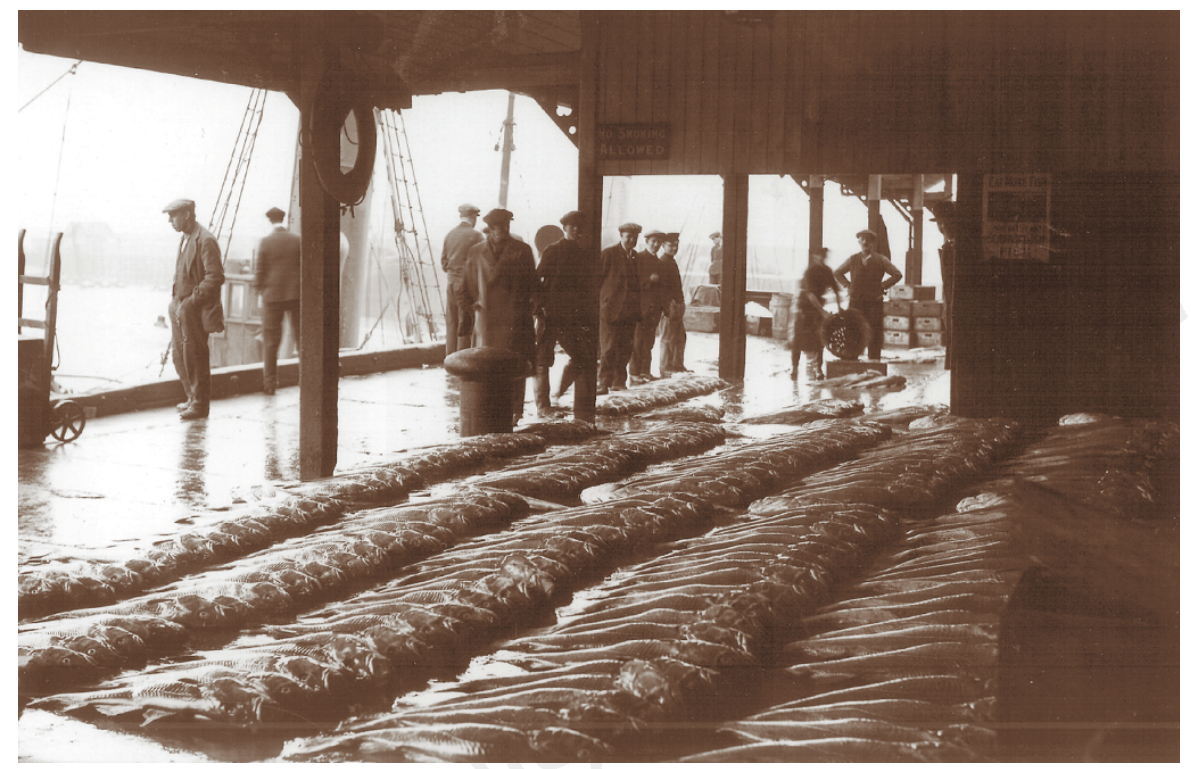

The catch at Scarborough in 1932, when North Sea fish stocks were healthier.

tion. In two world wars, when fishing ceased in the North Sea for several years, the stocks recovered dramatically, demonstrating both that fishing did affect the number of fish and that regulation could be effective. Moreover, excessive fishing since then has caused the collapse of stocks of herring off Norway, and of herring and mackerel in the North Sea, all previously measured in millions of tons. The most dramatic and notorious collapse has however been that of the cod stocks on the Grand Banks of Newfoundland.

The history of this once great fishery, and the fish that supported it, is the central theme of this fascinating book by Mark Kurlansky, once a fisherman himself. He follows the story from the 'discovery' of great shoals of fish, previously the secret of canny Basques, by Giovanni Caboto (alias John Cabot) in 1497, to the present day. In so doing, he ranges widely. The importance of dried and salted cod as a staple food, sustaining international trade from the Vikings, through the American Civil War, until Clarence Birdseye invented frozen fish, is vividly described. He relates its link to the slave trade, and the rise of the codfish aristocracy of Boston, and much else besides. The story is brought to life with amusing anecdotes, keen observations and telling quotations from conversations with fishermen, scientists and politicians from countries all around the North Atlantic. Rightly, he identifies no single culprit: most disasters occur when several things go wrong at once, and this seems to be no exception.

This is, however, much more than just a history of the cod fisheries. Nicely produced in a fashionably small format, the book contains many aptly chosen quotations, excellent illustrations and numerous recipes for preparing cod, especially the dried and salted varieties. Even if your opinion of the product, like mine, coincides with that of Auden and MacNeice, there is much to savour here.

With the latest research (Nature 385, 521; 1997) suggesting that the cod stock of the North Sea is teetering on the edge of collapse, this is, above all, a cautionary tale we would do well to heed. The oceans may be vast, and their resources great, but so is our capacity to harm them.

John Shepherd is at the Southampton

Oceanography Centre, University of Southampton, Empress Dock, Southampton SO14 3ZH, UK.

\section{Flights and fights}

\section{Concorde and the Americans: International Politics of the Supersonic Transport}

by Kenneth Owen

Smithsonian Institution Press: 1997. UK

publisher Airlife. Pp. 232. \$35, £24.95

\section{PaulDuffy}

The story of civil aviation and aircraft is usually told in terms of engineering, technical and marketing achievements, but equally interesting tales centre on the politics and economics of each important project.

This, according to the cover, is the story told in Concorde and the Americans. In fact, only two pages make any more than a passing reference to economics, and these, under the heading "uneconomy class", relate to figures from reports by British Airways and the former British Overseas Airways Corporation.

Concorde first took to the air in 1969 and has been flying daily services between New York and Europe for something over 20 years. But the development of supersonic transport (SST) was plagued by bitter political controversies over the environmental and economic effects and by strained relationships between the United 
States, France and the United Kingdom. Kenneth Owen recounts the transatlantic negotiations that led to the rise and demise of plans for an American SST, to the AngloFrench collaboration in building Concorde and to the battle for approval of the Concorde service to the United States.

The book is essentially compiled from available government documents-minutes of cabinet meetings, departmental minutes, reports commissioned by government and industry from advisers and consultants-and from court records, mainly from US courts which heard the suits brought by groups trying to prevent Concorde's access to New York and the subsequent appeals.

It is therefore a useful reference book for future historians and researchers interested not only in the Concorde programme but also in aviation, technical and environmental questions that may arise in the future.

Owen covers all these aspects well, from both the UK and US sides, and gives full details of his sources. But, apart from minor quotations from joint British Aircraft Corporation/Aerospatiale press releases and brief reports of two conferences on future SST held in Toulouse in 1990 and 1994, there is almost no material originating from France. Surely Concorde was a joint AngloFrench programme?

Owen does, however, make clear the difficulties of international programmes involving different bureaucracies, different programme targets and even different measurements-metric and imperial. Yet he outlines them only from a British point of view.

He shows that the French president and government were totally pro-Concorde; but that Harold Macmillan's government, thinking the French might back out of the programme after a few years, decided that no escape clause should be included in the two countries' Concorde treaty. This effectively locked Britain, but not France, into a technologically successful but financially disastrous and increasingly expensive programme.

We also learn that a main motivation for the Anglo-French programme was the belief that the United States was only a few years behind in developing its own SST. When environmental issues first infringed on aviation in the late 1960s and early 1970s, they became a critical factor in the cancellation of the US rival project. It quickly became evident that only the British and French national airlines would take and operate Concorde.

Regrettably, the author assumes that the reader is fully conversant with the environmental questions, and the huge political problems they raised for all technological matters at and since that time. Some background would have been useful.

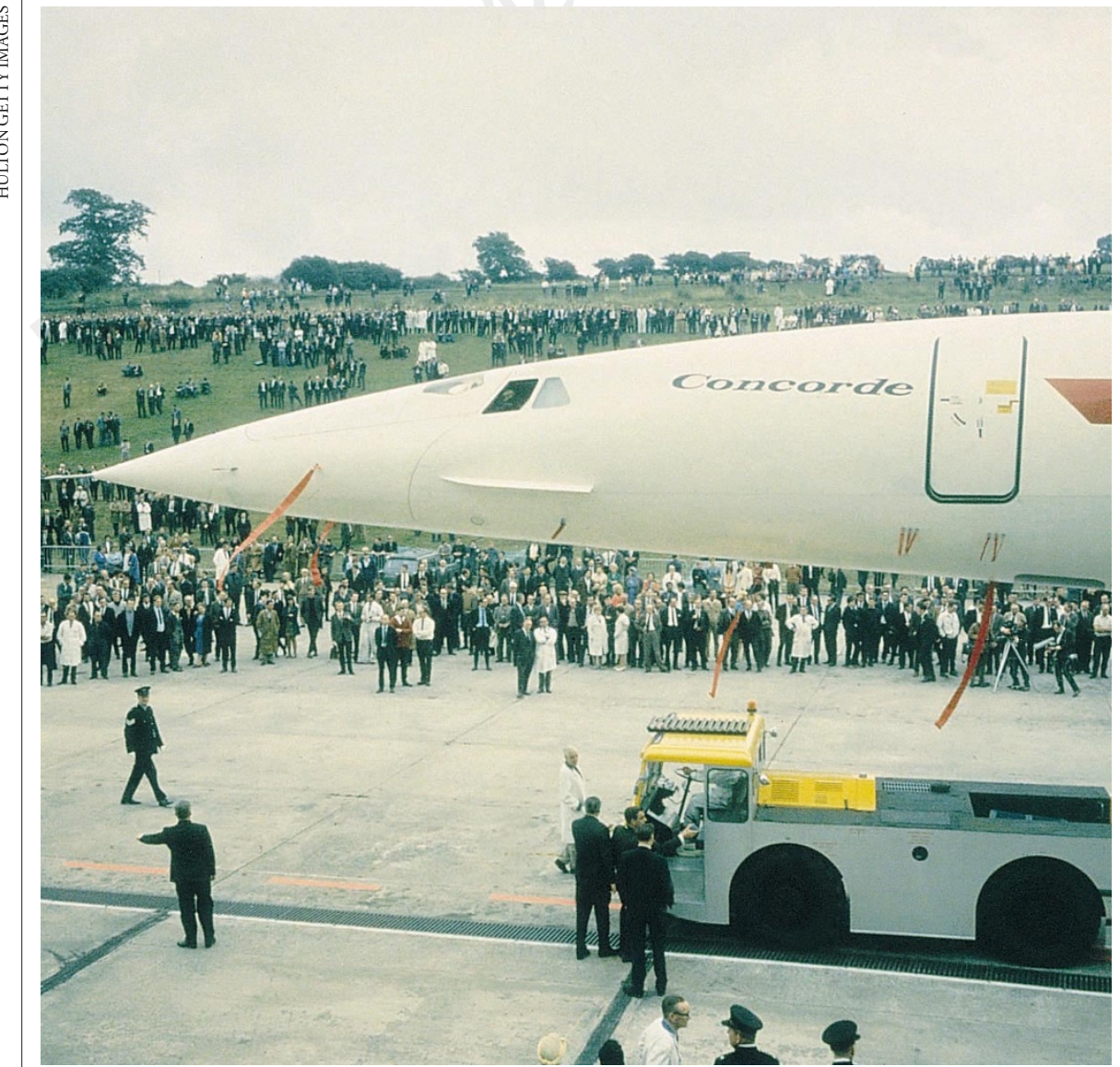

Bumpy ride ahead: Concorde makes one of its earliest public appearances, in 1968.
International partnership was deemed necessary by Europe's aviation industry and its governments because of the high cost of developing the new technology for the next major step in civil aviation, which is how supersonic transport was seen in the 1950s and 1960s.

Unfortunately, and with hindsight, there were two inherent mistakes in this assumption: that the United States would be a partner when in fact it was not anxious to share in any joint project and felt it could go it alone; and that the immediate future of commercial air transport would be shaped by SST rather than high-capacity subsonic airliners - the 747, DC-10 and Tristar, built by the three giant US corporations Boeing, McDonnell Douglas and Lockheed. Europe delayed its entry into this important market by not seeing the signs early enough.

Indeed, the Bermuda Convention, where the United Kingdom and the United States agreed to recognize each other's airworthiness certification requirements, resulted in the approval of new US wide-body planes for British operation while Concorde ran into considerable difficulties in the United States.

Owen deals well with some of the environmental aspects. He points out that Concorde is still the only aircraft that has been required to undergo an environmental impact study. And he reveals how federal aviation requirements on noise and pollution were the focus for opponents trying to prevent Concorde flying to the United States.

He also shows that the US secretary for transportation, William T. Coleman, displayed a sound practical and judicial approach to settling the prolonged question of Concorde access, in part by leaving potential grounds for appeals for the courts to decide.

Coleman combined a sense of fairness towards the Concorde countries with an awareness of political reality by allowing a trial period of 16 months to determine whether approval would be longterm or not.

Owen concludes the book with a detailed look at future SST, concluding that larger subsonic aircraft will come first. He foresees considerable investment initially in 1,000-passenger aircraft for main routes rather than a 300-seater Mach 2/Mach 3 plane. And he queries the demand for a "son of Concorde" from the world's airlines.

He makes some mention of the other existing SST, the Soviet Tu-144. Sadly, the (mostly inaccurate) remarks about this reflect perceived Western opinion rather than the actuality.

Paul Duffy is at 9 Deilginis, Shannon, County Clare, Ireland. 